Olgu Sunumu/Case Report

\title{
Nadir splanik ven trombozu sebebi: Faktör V leiden mutasyonu
}

\author{
A rare cause of splanic vein trombosis: Factor $V$ leiden mutation is \\ Kadir Dicle*, Ali N. Ulusoy, Hamza Çınar, Mümin Demir, Temel Deniz Şeren, Tugrul Kesicioğlu \\ Ondokuz Mayls Üniversitesi, Tıp Fakültesi, Genel Cerrahi Anabilim Dalı, Samsun
}

\begin{tabular}{|c|c|}
\hline MAKALE BİLGÍLERİ & ÖZET \\
\hline Makale Geçmişi: & \multirow{4}{*}{$\begin{array}{l}\text { Pıhtılaşma, kanda bulunan } 20 \text { kadar pıhtılaşma faktörünün ardışı reaksiyonu sonucu orta- } \\
\text { ya çıan bir olaydır. Bunlardan bazılarının mutasyonu sonucu ortaya çıkan bozukluklarda } \\
\text { damar içinde trombüs oluşumu ve/veya kanama görülebilir. Altı yıl önce akut karın tanı- } \\
\text { sıyla ameliyat edilen hastada vena mesenterica superiorda oklüzyon mevcuttu. Bu damarın } \\
\text { direne ettiği yaklaşık } 70 \mathrm{~cm} \text { 'lik bağırsak segmentinin rezeksiyonu ve uç-uca anostomo- } \\
\text { zu yapıldı. Ameliyat sonrası yapılan incelemelerde; Faktör V Leiden (FVL) mutasyonu } \\
\text { bulundu. Altı yıl sonra karın şişliği nedeniyle tekrar hastaneye başvuran hastada, yapılan } \\
\text { incelemelerde portal ven trombozu tanısı konularak uygun tedavi planlandı. Bu yazıda bu } \\
\text { olgunun tanı ve tedavi yaklaşımları sunulmaktadır. } \\
\text { J. Exp. Clin. Med., 2009; 26:196-198 }\end{array}$} \\
\hline Geliş $\quad 19 / 12 / 08$ & \\
\hline $20 / 11 / 09$ & \\
\hline $\begin{array}{l}\text { * Yazışma Adresi: } \\
\text { Kadir Dicle } \\
\text { Ondokuz Mayıs Üniversitesi, } \\
\text { Tıp Fakültesi, Genel Cerrahi } \\
\text { Anabilim Dalı, }\end{array}$ & \\
\hline
\end{tabular}

Kurupelit, Samsun

e-posta : kdicle19@mynet.com

\section{Anahtar Kelimeler: \\ Faktör V Leiden Mutasyonu \\ Cerrahi Müdahele \\ Erken Tanı \\ Trombüs Oluşumu \\ Pıhtılaşma Faktörü \\ Anastomoz}

Key Words:

Factor V Leiden Mutation

Surgical Treatment

Early Diagnosis

Thrombus Constituon

Clotting Faktör

Anastomosis

\begin{abstract}
Clotting is a process that occurs following the consecutive reactions of almost 20 different molecules in the blood. The diseases that appear due to the mutation of these molecules resulted in, intravascular thrombus bleeding. Our case who admitted to our hospital due to acute abdominal pain six year before was operated under the emergency conditions and superior mesenteric vein occlusion was observed. Partial resection of $70 \mathrm{~cm}$ small intestine with end to end anostomosis was performed. Faktör V leiden mutation was found in the postoperative diagnostic investigations Six year later, the same patient was admitted to our clinic with abdominal distention and diagnosed to be portal vein thrombosis and appropriate treatment was in this report, we presented the diagnostic and treatment characteristics of the case.

J. Exp. Clin. Med., 2009; 26:196-198
\end{abstract}

(C) 2009 OMÜ Tüm Hakları Saklıdır.

\section{Giris}

FVL mutasyonunda protein C'nin aktivitesine direnç göstermesi sorumludur (Brttsh, 2001; Rozendaal ve ark., 1995). Mutasyon 506. aminoasit pozisyonundaki tek bir nükleik asitin yer değiştirmesi (Guanin $\rightarrow$ Adenin) sonucu oluşur (Rozendaal ve ark., 1995). Böylece hayati organlara giden damarlarda pıhtı oluşması sonucu ciddi sorunlar ortaya çıkabilir (Rozendaal ve ark., 1995; Brttsh, 2001; Lucotte ve ark., 2003). Bir canlıdaki genler 2 allel genden oluşur hem anneden hemde babadan gelirse homozigot, yalnızca birinden gelirse heterozigot denilir. FVL mutasyonunda her iki durumda da hastalık belirtileri ortaya çıkabilir. Heterozigotlarda pıhtılaşma komplikasyonu 4-5 kat artarken homozigotta bu oran 30-40 kat artmaktadir (Rosendaal ve ark., 1997; Segev ve ark., 2005).

Pıhtılaşmada, trombomodülün trombine dönüşür bu da Protein C ile birleşerek Aktive Protein C (APC) oluşturur, bu da trombosit üzerinde bulunan Protein $\mathrm{S}$ ile birleşerek faktör V ve faktör VIII'i inaktive eder (Ulutin ve ark., 2000). Böylece aşırı trombüs oluşumu önlenmiş olur. FVL mutasyonunda ise Aktive Protein C'nin, Protein S ile birleşmesi bozulduğundan, faktör V ve VIII aktivitesi artar 
ve damar içi trombüs oluşur. Bu da ciddi komplikasyonlara hatta ölüme neden olabilir (Eskandari ve ark., 2002).

Ayrıca bu mutasyonu taşıyan bireylerde venöz tromboz, periferik vasküler hastalıklar, felç, tekrarlayan düşük, pulmoner embolizm ve kalp krizi görülme riskinin arttırdığ 1 bildirilmiştir (Kupferminc ve ark., 1999). Bu nedenle trombofili için yüksek risk grubundaki bireylerin taranması oldukça önemlidir (Kupferminc ve ark., 1999).

$\mathrm{Bu}$ yazıda nadir görülen faktör $\mathrm{V}$ leiden mutasyonu sonucu süperior mezenter ven ve portal ven trombüsü ile kendini gösteren olgu sunulmuştur.

\section{Olgu sunumu}

52 yaşında erkek hasta altı yıl önce ani başlayan karın ağrısı şikayeti ile hastanemiz acil servisine başvurdu ve akut karın tanısıyla ameliyata alındı. Direk gözlemde ince barsağın jejeno-ileal bölümünde, yaklaşı $70 \mathrm{~cm}$ 'lik segmentte nekroz ve Süperior Mezenterik Vende (SMV) trombüs mevcuttu. $70 \mathrm{~cm}$ lik barsak segmenti çıkarılarak uç-uca anastomoz yapıldı. Diğer segmentler görünüm olarak dolaşımları normaldi. Yara iyileşmesinde problemi olmadı. Yapılan incelemelerde $\% 70$ oranında FVL mutasyonu olduğu bulundu. Hastaya Warfarin sodyum 1x5mg/gün (COUMADİN® $5 \mathrm{mg}$ Eczacıbaşı ilaç san. Tiç. A.Ş.) tedavisi başlandı 3 aylık aralıklarla kontrole gelmesi önerildi. 1 yıl önce karın ağrısı, halsizlik, yorgunluk ve karında şişlik şikayeti ile hastanemize tekrar başvurduğu saptandı. Hastanın son 5 aydır Coumadin ilacını kulanmadığ 1 öğrenildi.

Hastamız 7 yıl öncesine kadar 30 paket yıl sigara içmiş. Hastanın fizik incelemesinde karında distansiyonu olduğu bulundu Asit muayenesi pozitif idi. Karaciger normal boyutlarda iken dalağın kaburga kenarın $5 \mathrm{~cm}$ kadar geçtiği sabtandi. Hastanın yapilan laboratuvar incelenmesinde; Anti T3: \% 48, 9 (75-125) Aktive Protein C rezistansı: $0(0,8-1,6)$ Homosistein: 16,8 mikmol/dl (5-14) APTT : 36 saniye (2235) PT: \%16 (10-14 ) 1 NR: $1.28(0,85-1,15)$ D. Dimer: 546 mikro gr/dl (60-246) olduğu saptandı.

Yapılan dinamik + üst-alt abdomen bilgisayarlı tomografi incelenmesinde Karaciğer hilusunda, mide küçük kurvatur komşuluğunda dilate tortuaze vasküler yapılar izlendi. Portal ven kalibrasyonu azalmış ve lümenlerinde hipodens dolma defekti ( kronik trombus) mevcuttur. Özefagus çevresinde, mide kardia komşuluğunda, dalak hilusunda batın içi yağlı dokuda bol kolleteral vasküler yapılar mevcuttur. Batında perihepatik ve pelviste ve mezenterde serbest sivı gözlendi (Şek. 1).

Yine yapılan Manyetik Rezorans Anjiografi incelenmesinde; Süperior mezenterik ven lümeninden başlayıp portal ven ile devam eden hipointens trombüs görüldü. Karaciger hilusunda kavernöz transformasyon ile uyumlu kollateraller izlendi. Dalak hilusunda ve çevresinde kollateraller gözlendi (Şek. 2).

Hastaya düşük molekül ağırlıklı 2x0,6 cc (CLEXA-
NE® hazır enjektör 6000 IU/0,6ml Avantis Pharma San. Ve Tic. Ltd. Şti.) flakon başlandı, hastanın günlük INR si takip edilerek 2 seviyesinde tutuldu. Takibinde karın distansiyonu geriledi, oral diet başland, oral dieti tolere etti. Medikal tedavi ile portal ven trombozu gerileyan hastaya Warfarin sodyum başlandı, 3 ayda bir kontrole gelmesi önerilerek, taburcu edildi.

Hasta iki kez kontrole geldi İNR değeri 1,87 bulun$\mathrm{du}$, herhangi bir problem tespit edilmedi.

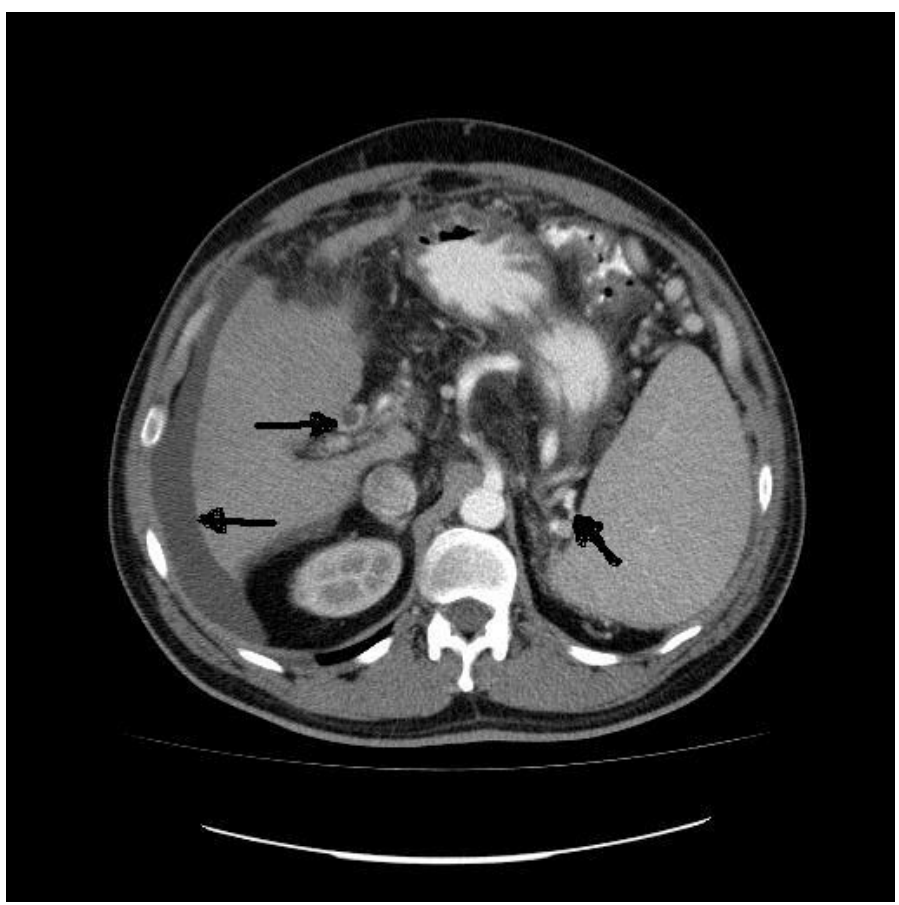

Şek. 1: Dinamik + üst- alt abdomen Bilgisayarlı Tomografi görüntüsü; Oklar: Karaciğer hilusunda portal ven trombozu, Dalak çevresinde kolleteral vasküler görüntüsü, Perihepatik alanda serbest mayi görüntüsünü göstermektedir.

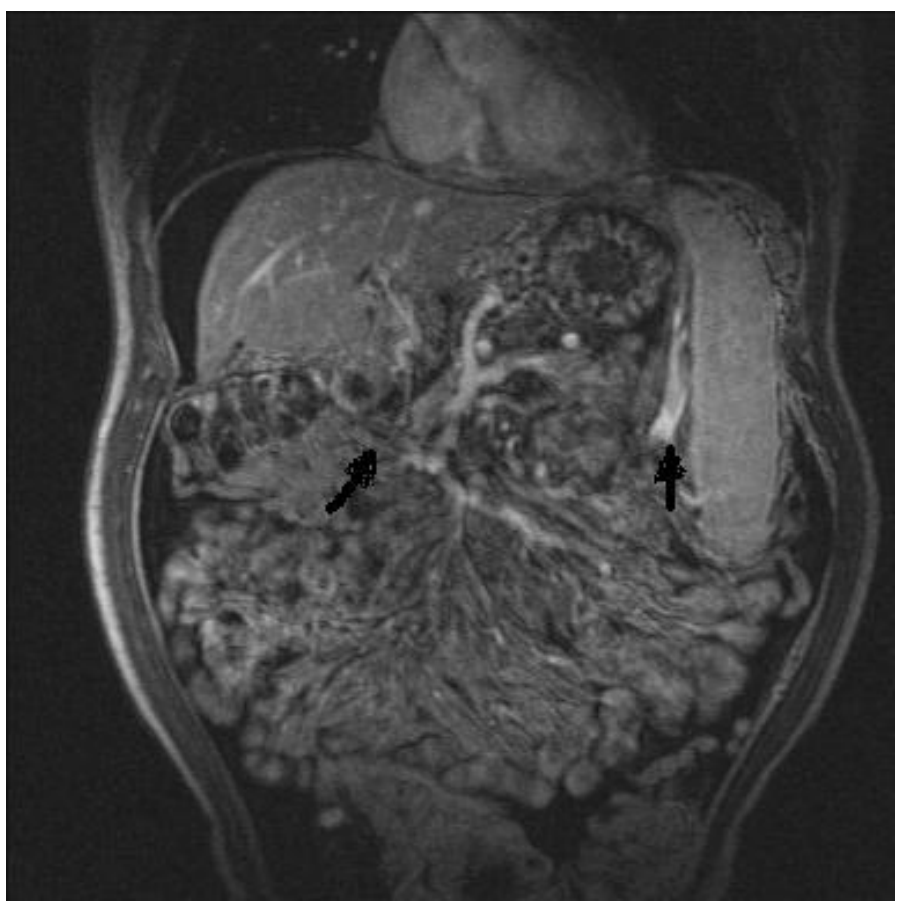

Şek. 2: Magnetik Rezorans Anjiografi görüntüsü; Oklar: Süperior mezenterik ven lümeninden başlayıp portal ven ile devam eden hipointens thrombus görüntüsü, Dalak hilusunda ve çevresinde kollateral vasküler görüntülsünü göstermektedir. 


\section{Tartışma}

Faktör V Leiden mutasyonu tanısı kanda aktive Protein $\mathrm{C}$ rezistansı testi ile konur. Kişinin heterozigot ya da homozigot olduğu ise yine kanda yapılacak genetik inceleme ile belirlenir. 50 yaştan önce anormal bir vende trombüs görülen kişilerde FVL mutasyonu araştırılmalıdır. Konuyla ilgili bilimsel dernek ve kuruluşlarca alınan tavsiye kararlarında FVL mutasyon taramasının yapılması önerilen durum ve kişiler şunlardır (Ridker ve ark., 1997; Kupferminc ve ark., 1999); 50 yaşından önce venöz tromboz geçirenler; tekrarlayan venöz tromboz atakları geçirenler; atipik damarlarda tromboz geçirenler (Ör: Portal vende); gebelikte, lohusalıkta ya da doğum kontrol hapı kullanırken venöz tromboz geçirenler; ailesinde venöz tromboz öyküsü olan kişilerde ilk kez venöz tromboz ortaya çıktığında; ailesinde bilinen FVL mutasyonu olanlar; gebeliğin ikinci ya da üçüncü trimesterinde nedeni açılanamayan ani gebelik kaybı öyküsü olanlar; gebeliklerinde açıklanamayan şiddetli preeklampsi, abruptio placenta ve rahim içi gelişme geriliği olanlar; 50 yaşından önce kalp krizi geçiren ve sigara içen kadınlar.

Aşağıda belirtilen durumlarda ise FVL mutasyonu taramasının yapılması önerilmemektedir; genel popülasyonda tarama amacıyla, hamilelik öncesi veya doğum kontrol hap1 kullanmaya başlamadan önce rutin test olarak, yenidoğanlarda rutin tarama testi olarak.

Ülkemizde FVL mutasyonunun heterozigot oranı \%7-8 iken homozigot oran1 \%0,025 dir (Ertürk ve ark., 2006). Heterozigotlarda, FVL mutasyonu olan kadınlar arasında oral kontraseptif kullananların trombüs riski 30-40 kat artarken, homozigotlarda bu oran yüzlerce kat artmaktadır (Rozendaal ve ark., 1995; Brttsh, 2001). Heterozigotlarda trombüs oluşma siklig1 4-8 kat artarken homozigotlarda bu oran 30 - 40 kat artmaktadır (Lucotte ve ark., 2001; Lucotte ve ark., 2003).

Sigara içenlerde bu oran daha da artmaktadır (Rosedaal ve ark., 1997; Segev ve ark., 2005). Bizim hastamız da 7 y1l öncesine kadar 30 paket yıl sigara kullanmıştır.

Yapılan litaretür çalışmalarında predispozan faktörlerinin bulunduğu mezenter ven oklüzyonuna bağlı olan iskemik barsak hastalıklarında geniş barsak rezeksiyonları yapmak zorunludur. Buda hastalarda kisa barsak sendromuna yol açarak besin emiliminin yetersiz olmasına dolayısıyla malnutrisyona, vitamin eksikliklerine, çocuklarda gelişme geriliğine, sıv1 emilimindeki bozukluğun yol açtığı dehidratasyon ve enfeksiyonlara yatkınlık oluşturmaktadır.

Sunulan olgu kanaatimizce cerrahlara iki önemli mesaj vermektedir; birincisi erken yaşta mezenter iskemisi nedeniyle barsak rezeksiyonu yapılan olgularda etyolojik neden mutlaka araştırılmalıdır. Çünkü ileride meydana gelebilecek yeni tromboz olaylarının önlenebilmesi etyolojinin aydınlatılmasına bağlıdır. Hastamızda sebep bulunduktan sonra antikoagülan tedavi başlanmıș.Ancak hastanın tedaviyi aksatmasindan dolayi portal vende ve splenik vende tekrar tromboz oluşmuştur. Kalıtsal tromboz hastalıklarında tanının erken konulması ileride ortaya çıkabilecek fetal komplikasyonların önlenmesi açısından önemlidir. İkincisi iskemi veya nekrozun gerektirdiği kadar geniş barsak rezeksiyonu yapmakta tereddüt edilmemelidir. İleoçekal kapağın ve treitz ligamentinin korunabildiği hastalarda, doğru beslenme desteği programıyla intestinal adaptasyon sanıldığından daha çabuk ve büyük boyutta olabilmektedir.

Bizim hastamızda da 6 y1l önce, 46 yaşında süperior mezenter vende trombüs oluşması sonucu mezenter iskemi oluşmuş. Erken tanı ve cerrahi tedavi neticesinde sadece $70 \mathrm{~cm}$ 'lik ince barsak rezeksiyonu ve uç uca anostomoz yapılarak hem kisa barsak sendromundan korunmuş hemde kısa barsak sendromu sonucu oluşabilecek komplikasyonlardan korunmuş oldu böylece FVL mutasyonu sonucu oluşan komplikasyonun tedavisi cerrahi olarak yapıldı.

\section{KAYNAKLAR}

Brttsh, 2001. Committee for standarts in Heamtology. Guldelines on lnvestlgation and management of herltable thrombophillia. Br. J. Haematol.

Ertürk, C., Düzovalı, Ö., Muşlu, N., 2006. Faktör V Leiden Mutasyonunun Türkiye'deki Dağılımı. Sayı 2.

Eskandari, G., Demirkan, F., Eskandari, M.M., Yazar, M., Sucu, N., Aydın, S., Atik, U., 2002. Cerrahi Girişim Yapılacak Hastalarda Factor V Leiden ve Protrombin G20210A mutasyonlarının Prevelansı. Mersin Ünv. Tip Fak. Derg. 4, 389-392.

Kupferminc, M.J., Eldor, A., Steinman, N., Many, A., Bar-Am, A., Jaffa, A., Fait, G., Lessing, J.B., 1999. Increased frequency of genetic thrombophilia in women with complications of pregnancy. N. Engl. J. Med. 29, 341-384.

Lucotte, G., Mercier, G., 2001. Population Genetics of Factor V Leiden in Europe. Blood Cells, Molecules, and Diseases. 27, 362-367.

Lucotte, G., Champenois, T., 2003. Dublex PCR-RFLP for simultaneous detection of Factor V Leiden and Prothrombin G20210A, Mol. Cell. Probes. 17, 267-269.

Ridker, P.M., Miletich, J.P., Hennekens, C.H., Buring, J.E., 1997. Ethnic distribution of Factor V Leiden in 4047 men and women. Implications for venous thromboembolism screening. JAMA 277, 1305-1307

Rosendaal, F.R., Koster, T., Vanderbroucke, 1995. High risk of trombosis in pattents homozygosus for Factor V leiden activated protein $\mathrm{C}$ resistance. Blood.

Rosendaal, F.R., Siscovick, D.S., Schwartz, S.M., Psaty, B.M., Raghunathan, T.E, Vos, H.L., 1997. A common prothrombin variant (20210 $G$ to $A$ ) increases the risk of myocardial infarction in young women. Blood. 90, 1747-1750.

Segev, A., Ellis, M.H., Segev, F., Friedman, Z., Reshef, T., Sparkes, J.D., Tero, J., Pauzner, H., David, D., 2005. High prevelance of thrombophilia among young patients with myocardial infarction and few conventional risk factors. International J. Cardiol. 98, 421424.

Ulutin, T., Cengiz, M., Yüksel, A., 2000. Tıbbi Biyolojik Bilimler Bölümü Tıbbi Biyoloji Ders Notları 1, Nobel Tıp Kitapevleri. 45-109. 